\title{
The Role of Environmental Tax in Alleviating the Impact of Environmental Pollution on Residents' Happiness in China
}

\author{
Yu Liu ${ }^{1}$, Rong-Lin $\mathrm{Li}^{1}$, Yang Song ${ }^{1}$ and Zhi-Jiang Zhang ${ }^{2, *}$ \\ 1 College of Management, Wuhan Institute of Technology, Wuhan 430205, China; lyu429@163.com (Y.L.); \\ ronglin722@163.com (R.-L.L.); summersong95@163.com (Y.S.) \\ 2 Department of Preventive Medicine, School of Health Sciences, Wuhan University, Wuhan 430072, China \\ * Correspondence: zhang22968@whu.edu.cn; Tel.: +86-27-6847092
}

Received: 22 October 2019; Accepted: 18 November 2019; Published: 19 November 2019

\begin{abstract}
Background: Environmental tax has been implemented by the government in response to the demands of the residents to control environmental pollution. However, a tax has a wide effect on many interacting aspects of the society. It remains unknown whether enacting an environmental tax for the government can improve the residents' happiness. This study aimed to examine the impact of air and water pollution on residents' happiness and evaluate whether an environmental tax can alleviate the impact of air and water pollution on residents' happiness. Methods: Based on the 2015 Chinese General Social Survey Data, 28 provinces in China were divided into two categories according to their environmental tax rates: baseline-tax areas $(n=13)$ and high-tax areas $(n=15)$. The ordered probit model was used to analyze the impact of air and water pollution on the residents' happiness in baseline-tax areas and high-tax areas, respectively. The Chow Test was used to test whether the impact of environmental pollution on happiness was different between baseline-tax areas and high-tax areas. Results: The impact of air pollution on residents' happiness was statistically significant in the baseline-tax areas (coefficient $-0.162,95 \%$ confidence interval $(\mathrm{CI})-0.239,-0.086, p<0.001$ ), but the significance was weakened in the high-tax areas (coefficient $-0.030,95 \% \mathrm{CI}-0.060,0.000, p=0.051$ ). The Chow Test showed that the absolute value of the regression coefficient in the baseline-tax areas was significantly higher than the value in the high-tax areas $(\mathrm{F}=12.712, p<0.001)$. Similarly, the impact of water pollution on residents' happiness was statistically significant (coefficient $-0.264,95 \% \mathrm{CI}-0.353$, $-0.174, p<0.001$ ) in the baseline-tax areas and in the high-tax areas (coefficient $-0.063,95 \% \mathrm{CI}-0.091$, $-0.035, p<0.001)$, but the Chow Test showed that the absolute value of the regression coefficient in the baseline-tax areas was significantly higher than the value in the high-tax areas $(\mathrm{F}=13.758, p<0.001)$. Conclusions: Both air and water pollution impair residents' happiness. The present study shows for the first time that enacting an environmental tax significantly alleviates the negative effect of air and water pollution on residents' happiness. The findings of the present study provide empirical evidence for the government to levy environmental tax.
\end{abstract}

Keywords: air pollution; water pollution; happiness; environmental tax; moderating effect

\section{Introduction}

The rapid economic growth in China has been accompanied with environment degradation. Previous studies show that self-reported life satisfaction has not increased in China as much as would be expected [1]. Environmental pollution can obviously, at least partly, explain this paradox [2-6]. 
Air and water pollution, as the major cause of environmental deterioration, seriously affect residents' psychological and physical health status [7]. It has been reported that air pollution is associated with increased annoyance [8], anxiety [9], and, more devastatingly, several mental disorders, such as depression $[10,11]$ and schizophrenia [12]. Furthermore, air pollution causes a variety of diseases, e.g., pneumonia, asthma, stroke, and heart diseases [13]. Water pollution mainly includes industrial wastewater discharge, pesticide penetration and urban domestic sewage discharge. Water pollution produces bad smells, odors, and strange colors, which stimulate the senses of the residents, weaken the residents' desire to travel, and impair the emotions of the residents [14]. In addition, water pollution increases the costs of water consumption and leads to inconvenience to residents' lives [15]. Furthermore, toxic substances in contaminated water may be absorbed into the body through drinking or food consumption, and threaten the health of residents, e.g., liver cancer [16].

Given that health status and psychological well-being are two important factors affecting happiness, the impact of air and water pollution on residents' life satisfaction have been a hot topic $[6,11]$. Most studies demonstrate that environment pollution has a negative impact on residents' happiness $[3,4,17,18]$. Several studies explored the relationship between environmental pollution and happiness in China [1,19-22]. Through an analysis of 210 million geotagged Weibo tweets in China, Zheng et al. revealed that air pollution was associated with lower happiness expressed in tweets [22]. Zheng used data on Chinese industrial air waste and water waste to explore the relationship between pollution and the happiness of residents in China, and it was found that there is a significant negative correlation between them [14].

It has been proposed that the government can address the externality problem of pollution by implementing an appropriate tax in order to internalize the social cost of polluting emissions [23,24]. Environmental taxes and fees have been used worldwide in response to the deteriorating quality of the environment. Since then, there have been a lot of empirical studies on the effect of environmental tax on pollution [25-29]. Gaube found that environmental taxes were useful in improving environmental quality on the condition of the positive marginal benefits of environmental taxes [30]. However, some studies obtained an opposite conclusion. For example, Metcalf used the input-output framework with fifty-eight industry sectors to estimate the impact of environmental tax, and found that the impacts of such a reform were likely to be modest [31]. Gemechu et al. found that both the environmental target and economic target were very hard to achieve in Spain [32].

It has been 40 years since China launched an environment tax/fee system. It is possible to evaluate the effectiveness of the policy on environmental protection and associated social welfare in China. There are limited studies focused on this topic and they have reached different conclusions [33]. Some studies reported that the environmental tax system has exerted an effect on controlling air pollution [34-36]. Wang and Wheeler found that air and water pollution charges in China have exerted a positive effect on sewage control [37]. Li and Masui also found that the environmental tax could help reduce emissions of most kinds of pollutants base on the computable general equilibrium (CGE) model [38]. Ren also affirmed that the market-oriented environmental policy tools were beneficial to improving regional ecological efficiency [39]. Other studies reported that environmental tax failed to play a role in curbing industrial pollution [40,41]. According to Shibli and Markandya, the pollutant charge was relatively ineffective in China, because it was casually dependent on the local government [42]. The effects of the environmental standard charge on air pollution reduction in Shandong Province in China were not significant in the studies by Yuan et al. [43] and Hui et al. [33].

Happiness is an important indicator reflecting the quality of people's livelihood [1]. Improving happiness has become one of the most important tasks for the government. Few studies have examined whether levying environmental tax policies has an effect on residents' happiness. Accordingly, this study aims to (1) examine the impact of air and water pollution on residents' happiness in China; and (2) evaluate whether an environmental tax can alleviate the impact of air and water pollution on residents' happiness based on the moderating effect model. The present study explores, for the first time, the impact of an environmental tax on the social system from the perspectives of residents' happiness. The findings 
of the present study will testify the moderating effect of environmental tax and provide evidence for the government to levy environmental tax. This happiness analysis approach can provide theoretical evidence for improvement in environmental tax for the government.

The rest of the paper is organized as follows. Section 2 reviews the policy background. Section 3 introduces the methods of the moderating model. Section 4 analyses the empirical results. Section 5 discusses the conclusion and the probable mechanism. Section 6 is on the limitations of the study.

\section{Policy Background}

During the period 1978-2017, China established and carried out a sewage charge system. The rate of charge changed several times. Provincial governments decide their pollutant charge rates independently in China, although the baseline criterion is designed at the national level [33]. Table 1 lists the sewage charge rates for sulfur dioxide $\left(\mathrm{SO}_{2}\right)$ in the air and Chemical Oxygen Demand (COD, an indirect indicator for determining the organic content in water systems, reflecting the overall status of water pollution) in the water for 28 provinces in 2014. In 2014, 13 of 28 provinces implemented a baseline-tax rate required by the central government, i.e., 0.6 yuan per pollution equivalent for $\mathrm{SO}_{2}$ and 0.7 yuan per pollution equivalent for the COD. The other 15 provinces used a rate of 1.2 yuan per pollution equivalent for $\mathrm{SO}_{2}$ and 1.4 yuan per pollution equivalent for COD. Beijing used a rate of 9.5 yuan per pollution equivalent for $\mathrm{SO}_{2}$ and 10 yuan per pollution equivalent for $\mathrm{COD}$ (Table 1). These areas were defined as high-tax areas for the present study. On 1 January 2018, an environmental tax system was enacted to replace the former sewage charge system. The tax rates for each pollutant were roughly the same as the former sewage charge rates.

Table 1. The sewage charge rates for $\mathrm{SO}_{2}$ and Chemical Oxygen Demand (COD) in 28 provinces in 2014 in China (yuan/per pollution equivalent).

\begin{tabular}{cccccc}
\hline Province & $\mathrm{SO}_{2}$ & $\mathrm{COD}$ & Province & $\mathrm{SO}_{2}$ & $\mathrm{COD}$ \\
\hline Tianjin & 1.2 & 1.4 & Henan & 0.6 & 0.7 \\
Shanghai & 1.2 & 1.4 & Hubei & 0.6 & 0.7 \\
Beijing & 9.5 & 10 & Hunan & 0.6 & 0.7 \\
Chongqing & 0.6 & 0.7 & Guangdong & 1.2 & 1.4 \\
Hebei & 1.2 & 1.4 & Sichuan & 0.6 & 0.7 \\
Shanxi & 0.6 & 0.7 & Guizhou & 1.2 & 1.4 \\
Liaoning & 1.2 & 1.4 & Jiangxi & 0.6 & 0.7 \\
Jilin & 0.6 & 0.7 & Yunnan & 0.6 & 0.7 \\
Heilongjiang & 1.2 & 1.4 & Shaanxi & 0.6 & 0.7 \\
Jiangsu & 1.2 & 1.4 & Gansu & 0.6 & 0.7 \\
Zhejiang & 1.2 & 1.4 & Qinghai & 0.6 & 0.7 \\
Anhui & 1.2 & 1.4 & Inner Mongolia & 1.2 & 1.4 \\
Fujian & 0.6 & 0.7 & Guangxi & 1.2 & 1.4 \\
Shandong & 1.2 & 1.4 & Ningxia & 1.2 & 1.4 \\
\hline
\end{tabular}

Note: data were obtained from the provinces' environmental tax and sewage charge documents.

\section{Methods}

\subsection{Data Resource}

Data on residents' happiness were obtained from the latest Chinese General Social Survey Data (CGSS) 2015. The total sample size of the CGSS is 10,968, comprised of participants from 28 provinces of the 31 mainland provinces in China exclusive of Hainan, Xinjiang and Tibet, and is regarded as a nationally representative survey. For the present study, a total of 7 variables were extracted, i.e., happiness, gender, age, religion, marriage, health and income. After removing those with missing values for any of the 7 variables, there were 10,752 (98.1\%) participants. 
Emissions data on industrial $\mathrm{SO}_{2}$ and industrial $\mathrm{COD}$ in 28 provinces were derived from the China Environmental Statistical Yearbook (2015). As the CGSS was carried out in 2014, the data corresponded to the pollution and sewage charge rates in 2014. The $\mathrm{SO}_{2}$ and COD environmental tax rates were acquired from the publicly available official documents or website of each provincial government.

\subsection{Model Specifications}

The empirical model used in the present study was as follows:

$$
\begin{aligned}
& \text { Happiness }_{n}=\alpha_{1} \ln \text { Pollution }_{n i}+\beta_{1} Y_{n}+\varepsilon_{1} \\
& \text { Happiness }_{n}=\alpha_{2} \ln \text { Pollution }_{n i}+\beta_{2} Y_{n}+\varepsilon_{2}
\end{aligned}
$$

In Equations (1) and (2), $\alpha$ and $\beta$ are the regression coefficients of the equations, $\varepsilon$ is the error term of the regression model, Happiness ${ }_{n}$ represents the happiness of the $\mathrm{n}$ residents, Pollution $A_{n i}$ represents the degree of air pollution in the $i$ province of the $\mathrm{n}$ residents, Pollution $W_{n i}$ represents the degree of water pollution in the $i$ province of the $n$ residents, and $Y_{n}$ represents the collection of control variables of the $n$ residents. Residents' happiness is an ordered variable, ranking between 1 and 5 , so we use the ordered probit model to estimate Equations (1) and (2) [4].

\subsection{Dependent Variables}

Residents' happiness (Happiness). We selected the 36th question in CGSS 2015: "Generally speaking, do you think your life is happy?". There are five choices, i.e., very unhappy, unhappy, it is hard to say happy or unhappy, happy and very happy. The five choices were assigned values from 1 to 5 , correspondently.

\subsection{Independent Variables}

Air pollution (PollutionA). Industrial $\mathrm{SO}_{2}$ emission is the main cause of the increase in PM2.5, and is more irritating to humans. Therefore, we selected industrial $\mathrm{SO}_{2}$ emission as a proxy variable for air pollution level [44]. The logarithmic transformation was used for industrial $\mathrm{SO}_{2}$ emission.

Water pollution (PollutionW). COD is widely used in water quality monitoring in China. We selected industrial COD emission as a proxy variable for water pollution levels. The logarithmic transformation was used for industrial COD emission.

\subsection{Moderator Variables}

The $\mathrm{SO}_{2}$ tax rates in 2014 were used as a moderator for the association between air pollution and residents' happiness, because the CGSS 2015 was carried out in 2014. Table 1 lists the $\mathrm{SO}_{2}$ sewage taxation/charge rates in 28 provinces in 2014. A total of 13 provinces (called baseline-tax area) used 0.6 yuan/pollution equivalent, and the other 15 provinces (called high-tax area) used higher rates $>0.6$ yuan/pollution equivalent. Therefore, the moderator variable (Tax1) in the present study was assigned a value of 0 when the tax rate was 0.6 yuan/pollution equivalent and 1 when the tax rate was $>0.6$ yuan/pollution equivalent.

The COD tax rates in 2014 were used as a moderator for the association between water pollution and residents' happiness. Table 1 lists the COD sewage taxation/charge rates in 28 provinces in 2014. A total of 13 provinces (called baseline-tax area) used 0.7 yuan/pollution equivalent, and the other 15 provinces (called high-tax area) used higher rates $>0.7$ yuan/pollution equivalent. Therefore, the moderator variable (Tax2) in the present study was assigned a value of 0 when the tax rate was 0.7 yuan/pollution equivalent and 1 when the tax rate was $>0.7$ yuan/pollution equivalent. 


\subsection{Control Variables}

We controlled a set of factors that could affect subjective happiness. Previous studies at the individual level show that age, gender, marriage, religion, health and family income status are closely correlated with residents' happiness $[1,4,14]$. Therefore, we used gender, age, age ${ }^{2}$, religion, marriage, health and income as control variables in the present study.

\subsection{Chow Test}

To test the difference between the coefficients from the model in the baseline-tax area and high-tax area, we used the Chow Test, which was widely used to test whether structural changes exist [45].

\section{Results}

\subsection{Descriptive Analyses}

In the present study, the proportion of males was 46.8\% (Table 2). Age ranged from 17 to 93 years, with an average age of 49.4 years. The proportion of married participants was $89.0 \%$. The resident self-reported health status is rated at 5 and the average health status is 3.608 . The resident self-reported family income status is rated at 5 and the average income status is 2.652. The average residents' happiness was 3.867. The average industrial $\mathrm{SO}_{2}$ emissions were 602,950 tons, and the average industrial COD emissions were 110,300 tons.

Table 2. Descriptive statistics.

\begin{tabular}{|c|c|c|c|c|c|c|}
\hline & Variables & Measures & Mean & $\begin{array}{l}\text { Standard } \\
\text { Deviation }\end{array}$ & Minimum & Maximum \\
\hline $\begin{array}{l}\text { Dependent } \\
\text { variable }\end{array}$ & Happiness & $\begin{array}{l}\text { The five levels of respondents' } \\
\text { self-reported happiness }\end{array}$ & 3.867 & 0.821 & 1 & 5 \\
\hline \multirow{2}{*}{$\begin{array}{l}\text { Independent } \\
\text { variable }\end{array}$} & $\begin{array}{l}\text { Air Pollution } \\
\text { (PollutionA) }\end{array}$ & Industrial $\mathrm{SO}_{2}$ emissions & 60.295 & 33.095 & 4.035 & 140 \\
\hline & $\begin{array}{l}\text { Water Pollution } \\
\text { (PollutionW) }\end{array}$ & Industrial COD emissions & 11.030 & 5.694 & 0.605 & 23.550 \\
\hline \multirow{7}{*}{$\begin{array}{l}\text { Control } \\
\text { variable }\end{array}$} & Gender & Male $=1 ;$ Female $=0$ & 0.468 & 0.499 & 0 & 1 \\
\hline & Age & The age of respondents & 49.402 & 16.895 & 17 & 93 \\
\hline & Age $^{2}$ & The square of age & 2725.960 & 1708.599 & 289 & 8649 \\
\hline & Religion & Religion $=1 ;$ No religion $=0$ & 0.109 & 0.312 & 0 & 1 \\
\hline & Marriage & Married $=1 ;$ Others $=0$ & 0.890 & 0.313 & 0 & 1 \\
\hline & Health & $\begin{array}{l}\text { The five levels of respondents' } \\
\text { health }\end{array}$ & 3.608 & 1.075 & 1 & 5 \\
\hline & Income & $\begin{array}{l}\text { The five levels of respondents' } \\
\text { family income status }\end{array}$ & 2.652 & 0.717 & 1 & 5 \\
\hline \multirow{2}{*}{$\begin{array}{l}\text { Moderator } \\
\text { variable }\end{array}$} & Tax1 & Sewage charges $\left(\mathrm{SO}_{2}\right)$ & 1.338 & 1.894 & 0.6 & 9.5 \\
\hline & Tax2 & Sewage charges (COD) & 1.507 & 1.977 & 0.7 & 10 \\
\hline
\end{tabular}

\subsection{Empirical Results}

We used the STATA software to perform an ordered probit regression analysis of Equations (1) and (2). The regression result was shown in Table 3. The emission of industrial $\mathrm{SO}_{2}$ in air pollution had a negative impact on residents' happiness. The regression coefficient was $-0.059(95 \% \mathrm{CI}-0.086,-0.031)$ with $p<0.001$. The emission of industrial COD in water pollution had a negative impact on residents' happiness. The regression coefficient was $-0.089(95 \% \mathrm{CI}-0.116,-0.063)$ with $p<0.001$. The regression result indicated that the emission of industrial $\mathrm{SO}_{2}$ and COD significantly reduced residents' happiness, which was consistent with previous studies. In order to enhance the robustness of the regression result, the models contained the individual control variables, and the statistical significance of control variables was high, indicating that the effect of the regression analysis was robust, and the results of the individual feature control variables were basically similar to the previous studies [2]. 
Table 3. Regression results of environmental pollution effect on residents' happiness.

\begin{tabular}{|c|c|c|c|c|c|c|c|}
\hline \multicolumn{2}{|c|}{ Dependent Variable } & \multicolumn{6}{|c|}{ Happiness } \\
\hline \multirow{2}{*}{\multicolumn{2}{|c|}{ Independent Variable }} & \multicolumn{3}{|c|}{ PollutionA } & \multicolumn{3}{|c|}{ PollutionW } \\
\hline & & Coefficient & $95 \% \mathrm{CI}$ & $p$ Value & Coefficient & $95 \% \mathrm{CI}$ & $p$ Value \\
\hline & & -0.059 & $(-0.086,-0.031)$ & 0.000 & -0.089 & $(-0.116,-0.063)$ & 0.000 \\
\hline \multirow{7}{*}{$\begin{array}{c}\text { Control } \\
\text { Variable }\end{array}$} & Gender & -0.077 & $(-0.120,-0.034)$ & 0.000 & -0.075 & $(-0.118,0.032)$ & 0.001 \\
\hline & Age & -0.030 & $(-0.038,-0.022)$ & 0.000 & -0.030 & $(-0.038,-0.022)$ & 0.000 \\
\hline & $\mathrm{Age}^{2}$ & 0.000 & $(0.000,0.001)$ & 0.000 & 0.000 & $(0.000,0.001)$ & 0.000 \\
\hline & Religion & 0.139 & $(0.071,0.208)$ & 0.000 & 0.154 & $(0.085,0.223)$ & 0.000 \\
\hline & Marriage & 0.239 & $(0.152,0.325)$ & 0.000 & 0.249 & $(0.163,0.336)$ & 0.000 \\
\hline & Health & 0.237 & $(0.215,0.260)$ & 0.000 & 0.237 & $(0.214,0.259)$ & 0.000 \\
\hline & Finance & 0.416 & $(0.385,0.447)$ & 0.000 & 0.416 & $(0.384,0.447)$ & 0.000 \\
\hline \multicolumn{2}{|c|}{ Number of Observation } & \multicolumn{3}{|c|}{10752} & \multicolumn{3}{|c|}{10752} \\
\hline \multirow{3}{*}{\multicolumn{2}{|c|}{$\begin{array}{c}\text { Pseudo } R^{2} \\
\text { Log likelihood } \\
\text { Prob > chi2 }\end{array}$}} & \multicolumn{3}{|c|}{0.065} & \multicolumn{3}{|c|}{0.066} \\
\hline & & \multicolumn{3}{|c|}{$-11,289.057$} & \multicolumn{3}{|c|}{$-11,275.926$} \\
\hline & & \multicolumn{3}{|c|}{0.000} & \multicolumn{3}{|c|}{0.000} \\
\hline
\end{tabular}

\subsection{Moderating Effect Results}

In Table 4 , the coefficient of the $\mathrm{SO}_{2}$ sewage charge in baseline-tax areas was $-0.162(95 \% \mathrm{CI}$ $-0.239,-0.086)$ and statistically significant $(p<0.001)$, supporting a negative effect of air pollution on residents' happiness. Conversely, the coefficient of the $\mathrm{SO}_{2}$ sewage charge in high-tax areas was -0.030 (95\% CI $-0.060,0.000)$, indicating a weakened significance $(p=0.051)$. The Chow Test showed that the two coefficients in baseline- and high-tax areas were statistically different $(\mathrm{F}=12.712, p<0.001)$.

The coefficient of the COD sewage charge in baseline-tax areas was $-0.264(95 \% \mathrm{CI}-0.353,-0.174)$ and statistically significant $(p<0.001$, Table 4$)$, supporting a negative effect of water pollution on residents' happiness (Table 4). In contrast, the coefficient of the COD sewage charge in high-tax areas was $-0.063(95 \%$ CI $-0.091,-0.035)$ and statistically significant $(p<0.001)$. The Chow Test showed that the two coefficients in baseline- and high-tax areas were statistically different $(\mathrm{F}=13.758, p<0.001)$. 
Table 4. Environmental tax moderator effect test results.

\begin{tabular}{|c|c|c|c|c|c|c|c|c|c|c|c|c|c|}
\hline \multicolumn{2}{|c|}{ Dependent Variable } & \multicolumn{12}{|c|}{ Happiness } \\
\hline \multirow{4}{*}{\multicolumn{2}{|c|}{$\begin{array}{l}\text { Independent } \\
\text { Variable/Group }\end{array}$}} & \multicolumn{6}{|c|}{ PollutionA } & \multicolumn{6}{|c|}{ PollutionW } \\
\hline & & \multicolumn{3}{|c|}{ Baseline-Tax Area } & \multicolumn{3}{|c|}{ High-Tax Area } & \multicolumn{3}{|c|}{ Baseline-Tax Area } & \multicolumn{3}{|c|}{ High-Tax Area } \\
\hline & & Coefficient & $95 \% \mathrm{CI}$ & $p$ Value & Coefficient & $95 \% \mathrm{CI}$ & $p$ Value & Coefficient & $95 \% \mathrm{CI}$ & $p$ Value & Coefficient & $95 \% \mathrm{CI}$ & $p$ Value \\
\hline & & -0.162 & $(-0.239,-0.086)$ & 0.000 & -0.030 & $(-0.060,0.000)$ & 0.051 & -0.264 & $(-0.353,-0.174)$ & 0.000 & -0.063 & $(-0.091,-0.035)$ & 0.000 \\
\hline \multirow{7}{*}{$\begin{array}{l}\text { Control } \\
\text { Variable }\end{array}$} & Gender & -0.106 & $(-0.169,-0.042)$ & 0.001 & -0.056 & $(-0.115,0.002)$ & 0.059 & -0.105 & $(-0.169,0.042)$ & 0.001 & -0.055 & $(-0.113,0.004)$ & 0.067 \\
\hline & Age & -0.030 & $(-0.042,-0.017)$ & 0.000 & -0.029 & $(-0.040,-0.018)$ & 0.000 & -0.029 & $(-0.042,-0.017)$ & 0.000 & -0.030 & $(-0.041,-0.019)$ & 0.000 \\
\hline & $\mathrm{Age}^{2}$ & 0.000 & $(0.000,0.001)$ & 0.000 & 0.000 & $(0.000,0.001)$ & 0.000 & 0.000 & $(0.000,0.001)$ & 0.000 & 0.000 & $(0.000,0.001)$ & 0.000 \\
\hline & Religion & 0.208 & $(0.104,0.312)$ & 0.000 & 0.069 & $(-0.023,0.161)$ & 0.140 & 0.229 & $(0.126,0.333)$ & 0.000 & 0.084 & $(-0.008,0.176)$ & 0.073 \\
\hline & Marriage & 0.142 & $(0.003,0.280)$ & 0.046 & 0.295 & $(0.185,0.405)$ & 0.000 & 0.148 & $(0.009,0.287)$ & 0.037 & 0.311 & $(0.200,0.421)$ & 0.000 \\
\hline & Health & 0.249 & $(0.217,0.282)$ & 0.000 & 0.225 & $(0.195,0.256)$ & 0.000 & 0.248 & $(0.216,0.281)$ & 0.000 & 0.225 & $(0.195,0.256)$ & 0.000 \\
\hline & Finance & 0.461 & $(0.414,0.509)$ & 0.000 & 0.381 & $(0.340,0.422)$ & 0.000 & 0.463 & $(0.415,0.511)$ & 0.000 & 0.381 & $(0.340,0.422)$ & 0.000 \\
\hline \multirow{2}{*}{$\begin{array}{l}\text { Chow } \\
\text { Test }\end{array}$} & $\mathrm{F}$ & \multicolumn{6}{|c|}{12.712} & \multicolumn{6}{|c|}{13.758} \\
\hline & $p$ Value & \multicolumn{6}{|c|}{0.000} & \multicolumn{6}{|c|}{0.000} \\
\hline \multicolumn{2}{|c|}{ Obs } & \multicolumn{3}{|c|}{4973} & \multirow{2}{*}{\multicolumn{3}{|c|}{$\begin{array}{c}5779 \\
0.0579\end{array}$}} & \multicolumn{3}{|c|}{4973} & \multicolumn{3}{|c|}{5779} \\
\hline \multirow{2}{*}{\multicolumn{2}{|c|}{$\begin{array}{c}\text { Pseudo R }{ }^{2} \\
\text { Log likelihood }\end{array}$}} & \multirow{2}{*}{\multicolumn{3}{|c|}{$\begin{array}{c}0.0744 \\
-5142.1443\end{array}$}} & & & & \multicolumn{3}{|c|}{0.0759} & \multicolumn{3}{|c|}{0.0592} \\
\hline & & & & & & -61182294 & & \multicolumn{3}{|c|}{-5134.2228} & \multicolumn{3}{|c|}{-6110.2975} \\
\hline \multicolumn{2}{|c|}{ Prob>chi2 } & \multicolumn{3}{|c|}{0.000} & \multicolumn{3}{|c|}{0.000} & & 0.000 & & & 0.000 & \\
\hline
\end{tabular}




\section{Discussion}

This study evaluated whether environmental tax moderates the relation between environmental pollution and residents' happiness. Our analyses were stratified according to the tax rates. We found that industrial $\mathrm{SO}_{2}$ emissions impair residents' happiness, and the magnitude of influence was much greater in baseline-tax areas than in high-tax areas, indicating an alleviating effect of air pollution tax on the relationship between air pollution and residents' happiness. Second, we found that industrial COD emissions impair residents' happiness, and the magnitude of influence was much greater in baseline-tax areas than in high-tax areas, indicating an alleviating effect of water pollution tax on the relationship between water pollution and residents' happiness.

One of the findings of this study is that air and water pollution have a significant negative impact on residents' happiness. The findings are consistent with previous studies [1,4,18]. The direction of effect is the same, although the magnitude is different. Zheng et al. reported that industrial wastewater in 2008 had a significant negative effect on residents' happiness, and the coefficient was -0.123 [14]. In contrast, the coefficient in our study is -0.089 (baseline- and high-tax areas combined). The reason may be that water pollution has been alleviated in recent years. The negative effect in the baseline-tax areas (coefficient -0.264) is greater than in Zheng's results, and the effect in the high-tax areas (coefficient -0.063 ) is smaller than in Zheng's results. Luechinger used the German Socio-Economic Panel (GSOEP) containing information on individual life satisfaction to examine the impact of air pollution on life satisfaction [46]. The regression coefficient is -0.005 based on panel data for the period 1985-2003 consisting of 29,246 individuals. Di Tella and MacCulloch found that the happiness responses of approximately 350,000 people living in the Organization for Economic Cooperation and Development (OECD) between 1975 and 1997 are negatively correlated with the level of $\mathrm{SO}_{2}$ emissions [47]. Their coefficient is -0.003 . In contrast, the coefficient is -0.059 in the present study, which is greater than the results from Luechinger [46], Di Tella and MacCulloch [47]. The comparison between ours and other studies show that air pollution has a greater influence on residents' happiness in China than in those countries.

The most important finding of the present study is that environmental tax plays a moderator role on the relationship between environmental pollution and residents' happiness. Specifically, air and water pollution had a greater negative impact on residents' happiness in the baseline-tax areas than in the high-tax areas, indicating a moderating effect of environmental tax on the negative impact of air and water pollution on residents' happiness. The underlying mechanisms remain unclear but could be twofold. On the one hand, the taxation of pollutants can stimulate energy conservation and emission reduction [34,35], which in turn leads to decreased negative impact on residents' happiness. On the other hand, the revenue of environmental tax may improve social welfare if appropriately used [26].

\section{Conclusions}

Air and water pollution have already become a tough issue in China. Sewage control and improving the environment need public regulation measures. The present study analyzed the moderating effect of environmental tax on the relationship between environmental pollution and residents' happiness. Environmental pollution has a negative effect on residents' happiness, and the present study shows for the first time that enacting an environmental tax significantly alleviates the negative effect of air and water pollution on residents' happiness. The findings of this study have important policy implications. First, although the effect of environmental tax is controversial, the findings of the present study provide evidence for the government to levy environmental tax. Second, the optimal environmental tax criterion is still unclear, nevertheless, the empirical results may provide references for the policy makers. In China, local governments could raise the environmental tax rate, especially for the base-line tax areas. Local governments should exert a reasonable environmental tax rate to alleviate the effect of pollution on residents' happiness. In order to protect the local economy, local governments do not have the incentive to raise the environmental tax rate. On the one hand, the central government could raise the baseline-tax rate. On the other hand, residents' happiness could be taken into account by local officials. 
Future research could be undertaken to study the spatial interactions of tax rate changes between regions on pollution emission. Disentangling the potentially confounding effect of weather may be important for environmental pollution and happiness. Air pollution in Chinese cities is known to be highly sensitive to wind direction and speed, as pollutants are carried from neighboring cities. Some large watershed and lakes span several provinces, such as Yangtze River, Yellow River and Poyang Lake. Pollution upstream may affect the environment downstream. In this sense, there could be some potential spatial interactions. However, due to limited data, we did not consider spatial interactions in this paper.

Author Contributions: Y.L. drafted the paper and designed the methodology; R.-L.L. and Y.S. interpreted the data; R.-L.L. analyzed the data; Y.L. wrote the original paper; Z.-J.Z. supervised the study and edited the paper.

Funding: This research was funded by the Humanities and Social Sciences Major Projects of Hubei Education Department, grant number 18ZD022.

Conflicts of Interest: The authors declare no conflict of interest.

\section{References}

1. Yang, J.; Zhang, Y. Price of air pollution: An analysis based on happiness data. World Econ. 2014, 37, 162-188.

2. Easterlin, R.A. Will raising the incomes of all increase the happiness of all? J. Econ. Behav. Organ. 1995, 27, 35-47. [CrossRef]

3. Ferreira, S.; Moro, M. Income and preferences for the environment: Evidence from subjective well-being data. Environ. Plan. A 2013, 45, 650-667. [CrossRef]

4. Levinson, A. Valuing public goods using happiness data: The case of air quality. J. Public Econ. 2012, 96, 869-880. [CrossRef]

5. Mackerron, G.; Mourato, S. Life satisfaction and air quality in London. Ecol. Econ. 2009, 5, 1441-1453. [CrossRef]

6. Hoogerbrugge, M.M.; Burger, M.J. Neighborhood-Based social capital and life satisfaction: The case of Rotterdam, The Netherlands. Urban Geogr. 2018, 39, 1484-1509. [CrossRef]

7. Salomon, J.A.; Wang, H.; Freeman, M.K.; Vos, T.; Flaxman, A.D.; Lopez, A.D.; Murray, C.J. Healthy life expectancy for 187 countries, 1990-2010: A systematic analysis for the Global Burden Disease Study 2010. Lancet 2012, 380, 2144-2162. [CrossRef]

8. Bénédicte, J.; Jordi, S.; Bertil, F.; Thomas, G.T.; Lucy, B.O.; Ursula, A.L.; Roberto, D.M.; Joachim, H.; Deborah, J.; Kjell, T. Annoyance due to air pollution in Europe. Int. J. Epidemiol. 2007, 36, 809-820.

9. Xu, W.; Ding, X.; Zhuang, Y.; Yuan, G.; An, Y.; Shi, Z.; Hwa, G.P. Perceived haze, stress, and negative emotions: An ecological momentary assessment study of the affective responses to haze. J. Health Psychol 2017, 135910531771760. [CrossRef]

10. Wang, R.; Xue, D.; Liu, Y.; Liu, P.; Chen, H. The relationship between air oollution and depression in China: Is neighbourhood social capital protective? Int. J. Environ. Res. Public Health 2018, 15, 1160. [CrossRef]

11. Zhang, X.; Zhang, X.B.; Chen, X. Happiness in the air: How does a dirty sky affect mental health and subjective well-being? J. Environ. Econ. Manag. 2017, 85, 81-94. [CrossRef] [PubMed]

12. Gao, Q.; $\mathrm{Xu}, \mathrm{Q}$.; Guo, X.; Fan, H.; Zhu, H. Particulate matter air pollution associated with hospital admissions for mental disorders: A time-series study in Beijing, China. Eur. Psychiatry 2017, 44, 68-75. [CrossRef] [PubMed]

13. James, G.W.; Robert, U.; Edward, A.; Kiros, B.; Rob, M.; Edward, R.; Roger, C.; Fred, L.; Frank, G. Association of improved air quality with lung development in children. New Eng. J. Med. 2015, 372, 905-913.

14. Zheng, J.; Liu, C.; Li, C. The impact of environmental pollution on happiness of Chinese. Wuhan Univ. J. Philos. Soc. Sci. 2015, 68, 66-73.

15. Suresh, K. What works to make cities good for living? J. Health Manag. 2016, 18, 367-380. [CrossRef]

16. Sun, J.; Huang, H.; Xiao, G.X.; Feng, G.S.; Yu, S.C.; Xue, Y.T.; Wan, X.; Yang, G.H.; Sun, X. Spatial distribution of liver cancer incidence in Shenqiu County, Henan Province, China: A spatial analysis. Biomed. Environ. Sci. 2015, 28, 214-218.

17. Ferreira, S.; Moro, M. On the use of subjective well-being data for environmental valuation. Environ. Resour. Econ. 2010, 46, 249-273. [CrossRef] 
18. Welsch, H. Environment and happiness: Valuation of air pollution using life satisfaction data. Ecol. Econ. 2005, 58, 801-813. [CrossRef]

19. Yuan, L.; Shin, K.; Managi, S. Subjective well-being and environmental quality: The impact of air pollution and green coverage in China. Ecol. Econ. 2018, 153, 124-138. [CrossRef]

20. Zhang, X.; Zhang, X.; Chen, X. Valuing air quality using happiness data: The case of China. Soc. Sci. Electron. Publ. 2017, 137, 29-36. [CrossRef]

21. Smyth, R.; Mishra, V.; Qian, X. The environment and well-being in urban China. Ecol. Econ. 2008, 68, 547-555. [CrossRef]

22. Zheng, S.; Wang, J.; Sun, C.; Zhang, X.; Kahn, M.E. Air pollution lowers Chinese urbanites' expressed happiness on social media. Nat. Hum. Behav. 2019, 3, 237-243. [CrossRef] [PubMed]

23. Pigou, A.C. The Economics of Welfare; McMillan \& Co.: London, UK, 1920.

24. Goulder, L.H. Environmental taxation and the double dividend: A reader's guide. Int. Tax Public Financ. 1995, 2, 157-183. [CrossRef]

25. Al-mulali, U.; Fereidouni, H.G.; Lee, J.Y.M.; Sab, C. Exploring the relationship between urbanization, energy consumption, and $\mathrm{CO}_{2}$ emission in MENA countries. Renew. Sustain. Energy Rev. 2013, 23, 107-112. [CrossRef]

26. Bosquet, B. Environmental tax reform: Does it work? A survey of the empirical evidence. Ecol. Econ. 2000, 34, 19-32. [CrossRef]

27. Krass, D.; Nedorezov, T.; Ovchinnikov, A. Environmental taxes and the choice of green technology. Prod. Oper. Manag. 2013, 22, 1035-1055. [CrossRef]

28. Xu, J.; Li, J. Tax payment, social contribution for pollution prevention and happiness. Probl Ekorozw. Sustain. Dev. 2016, 11, 59-64.

29. Filipović, S.; Golušin, M. Environmental taxation policy in the EU-New methodology approach. J. Clean. Prod. 2015, 88, 308-317. [CrossRef]

30. Gaube, T. Second-best pollution taxation and environmental quality. Front. Econ. Anal. Policy 2005, 1, 1363.

31. Metcalf, G.E. Corporate tax reform: Paying the bills with a carbon tax. Public Financ. Rev. 2007, 35, 440-459. [CrossRef]

32. Gemechu, E.D.; Butnar, I.; Liop, M.; Castells, E. Economic and environmental effects of cotaxation: An input-output analysis for Spain. J. Environ. Plan. Manag. 2014, 57, 751-768. [CrossRef]

33. Shi, H.; Qiao, Y.; Shao, X.; Wang, P. The effect of pollutant charges on economic and environmental performances: Evidence from Shandong Province in China. J. Clean. Prod. 2019, 232, 250-256. [CrossRef]

34. Chen, S. Marginal emission reduction cost and China's environmental tax reform. Soc. Sci. China 2011, 3, 222.

35. Ye, J.; An, H. Can environmental taxes effectively control air pollution. China Ind. Econ. 2017, 5, 54-74.

36. He, Y.; Wen, C.; He, J. The influence of China Environmental Protection Tax Law on firm performance-Vidence from stock markets. Appl. Econ. Lett. 2019, 1-4. [CrossRef]

37. Wang, H.; Wheeler, D. Endogenous Enforcement and Effectiveness of China's Pollution Levey System; Policy Research Working Paper Series; The World Bank: Washington, DC, USA, 2000; p. 2336.

38. Li, G.; Masui, T. Assessing the impacts of China's environmental tax using a dynamic computable general equilibrium model. J. Clean. Prod. 2019, 208, 316-324. [CrossRef]

39. Ren, S.; Li, X.; Yuan, B.; Li, D.; Chen, X. The effects of three types of environmental regulation on eco-efficiency: A cross-region analysis in China. J. Clean. Prod. 2018, 173, 245-255. [CrossRef]

40. Lu, H.; Zhu, G. Analysis on the effect of environmental tax and fee policy in China. China Univ. Geosci. J. Soc. Sci. 2017, 17, 9-26.

41. Li, J.J.; Liu, Y. An empirical study on the pollution reduction effect of environmental taxes and fees in China. China Popul. Resour. Environ. 2015, 25, 84-91.

42. Shibli, A.; Markandya, A. Industrial pollution control policies in Asia: How successful are the strategies? Asian J. Environ. Manag. 1995, 3, 12-15.

43. Yin, Y. Environmental performance and financial performance of Green Mutual Fund-Evidence from China. Open J. Bus. Manag. 2017, 5, 680-698. [CrossRef]

44. Li, M. Environmental pollution, governmental regulation and the happiness sense of residents: An empirical analysis based on CGSS (2008) micro-survey Data. Mod. Econ. Sci. 2015, 5, 59-68.

45. Chow, G.C. Tests of equality between sets of coefficients in 2 linear regressions. Econometrica 1960, 28, 591-605. [CrossRef] 
46. Luechinger, S. Valuing air quality using the life satisfaction approach. Econ. J. 2009, 119, 482-515. [CrossRef]

47. Di Tella, R.; MacCulloch, R. Gross national happiness as an answer to the Easterlin Paradox? J. Dev. Econ. 2008, 86, 22-42. [CrossRef] 